Relations industrielles

Industrial Relations

\title{
Conflits et arbitrage
}

\section{Gérard Tremblay}

Volume 1, numéro 6, février 1946

URI : https://id.erudit.org/iderudit/1023932ar

DOI : https://doi.org/10.7202/1023932ar

Aller au sommaire du numéro

Éditeur(s)

Département des relations industrielles de l’Université Laval

ISSN

0034-379X (imprimé)

1703-8138 (numérique)

Découvrir la revue

Citer cet article

Tremblay, G. (1946). Conflits et arbitrage. Relations industrielles / Industrial Relations, 1(6), 3-7. https://doi.org/10.7202/1023932ar

Tous droits réservés (C Département des relations industrielles de l’Université Laval, 1946
Ce document est protégé par la loi sur le droit d'auteur. L’utilisation des services d'Érudit (y compris la reproduction) est assujettie à sa politique d'utilisation que vous pouvez consulter en ligne.

https://apropos.erudit.org/fr/usagers/politique-dutilisation/ 


\section{CONFLITS ET ARBITRAGE}

Les grèves gigantesques qui sévissent aux Etats-Unis émeu vent non seulement l'opinion publique américaine, elles fixent aussi l'attention des Canadiens dont les intérêts économiques sont liés intimement à ceux de ses voisins. Nous sommes touchés par la grève des industries de l'automobile et des appareils électriques; nous le serons davantage par celle de l'acier.

La question se pose à notre esprit : les ouvriers ont-ils raison, du fait de l'augmentation du coût dé la vie, de réclamer un relèvement de $30 \%$ des taux horaires de leurs salaires actuels? L'industrie est-elle en mesure, compte tenu de la limitation des prix, d'accorder une augmentation de cette importance?

Nous n'avons pas les données nécessaires permettant de répondre à ces questions. Disons avec la Commission d'enquête établie par le président Truman que la solution de compromis d'une augmentation de $181 / 2 \%$ apparait équitable.

Mais là n'est pas la question. Il est tout naturel, dans un régime de liberté, qu'il y ait des conflits d'intérêts entre patrons et ouvriers sur le taux du salaire, la durée du travail et les autres conditions de travail. Ce que nous voulons souligner ici est la carence d'une procédure sincèrement agréée de part et d'autre pour prévenir et régler ces conflits d'intérêts.

Grâce à la Loi nationale des relations ouvrières Wagner Act - (1), on a assez bien réussi à trouver une solution aux conflits de liberté syndicale provoqués par le refus de l'employeur de négocier de bonne foi avec les représentants accrédités de ses salariés; on a également éliminé les luttes de juridiction des syndicats rivaux par le mécanisme du contrôle démocratiquè des effectifs.

Il reste done à compléter l'œuvre d'assainissement des relations patronales-ouvrières en établissant une procédure efficace de règlement des conflits d'intérêts.

Le sens commun nous incline à nous tourner naturellement vers la procédure de conciliation directe. Il appartient aux parties intéressées de composer ellesmêmes leurs différends. Les orgamisations syndicales sont puissantes et peuvent rencontrer sur un terrain d'égalité les corporations financières ou industrielles les plus réputées. L'expérience révèle que des négociateus s éclairés et conciliants peuvent toujours, même après de laborieuses discussions, trouver un terrain d'entente. Malheureusement, la guerre a nui beaucoup au développement de la technique de la négociation directe. En vue de prévenir l'inflation, aux Etats-Unis comme au Canada, on a instauré le régime des contrôles publics

(1) Législation équivalente au Canada : Arrêté C.P. 1003 (1944) ; au Québec : Loi des relations ouvrières. des salaires et des prix. Des organismes à pouvoirs très étendus, tels les Conseils du Travail en temps de guerre, rendaient jugement après audition des parties. Patrons et ouvriers ont ainsi un peu perdu l'habitude de régler eux-mêmes leurs affaires. Il faudra revenir au plus tôt, si l'on veut maintenir une liberté vraiment démocratique, au régime de la négociation directe.

Il est raisonnable, par ailleurs, qu'advenant la faillite des négociations directes, l'Etat intervienne pour aider à la reprise des pourparlers et au rapprochement des parties et provoque un règlement par voie de compromis. Les Etats-Unis, comme le Canada, ont largement développé les procédures de médiation. Tout département du Travail met à la disposition des employeurs et des salariés un nombre suffisant de techniciens pour les aider à régler leurs différends.

La conciliation même la plus habile et la plus zélée ne donne pas toujours de résultat. Il faut alors recourir à la dernière procédure possible, l'arbitrage, si l'on ne veut pas que les parties au conflit tentent de se faire justice elles-mêmes en recourant à leur force économique respective et aux armes de la grève et du lock-out.

L'arbitrage n'est pas seulement utile dans notre vie industrielle, il est nécessaire. L'institution est séculaire mais elle est toujours de mode et elle constitue l'un de moyens d'assurer la justice. Si les adversaires en présence ne peuvent se faire justice eux-mêmes, ils doivent recourir à une autorité qui la leur dispensera. Cette autorité, elle peut être un tribunal d'arbitrage, un simple arbitre, ou mieux, un tribunal du travail. Cette autorité peut être aussi une commission d'enquête qui rapportera ses conclusions non seulement aux parties en lutte mais à l'opinion publique c'est le cas des Fact Finding Commissions du président Truman.

Quel que soit l'organisme établi, il importe que celui-ci soit impartial et qu'il ait en vue d'assurer le bien commun dans le respect de la justice. Le recours à la procédure d'arbitrage doit être obligatoire autrement le bien commun est desservi. Il n'est pas juste que des associations ou des corporations s'astreignent librement à des disciplines de bien commun alors que d'autres les répudient par esprit de violence ou de dictature.

Les ouvriers ou les employeurs sont mal inspirés s'ils s'opposent à la procédure d'arbitrage obligatoire des conflits d'intérêts. Que dirait-on si, sur le plan international, une nation puissante continuait de revendiquer le droit de se faire justice elle-même quand elle se crojt lésée? Comment pourrait-on établir sur des bases solides une société des nations en tolérant cette autarcie

(Suite d la page 7 ) 


\section{A PROVINCIAL LABOUR CODE}

Note. For our readers' information, we quote hereinbelow an extract of the address delivered on the sixteenth of January 1946 by the Honourable Antonio Barrette, Minister of Labour of the Province of Quebec.

Now that we have entered the period of transition and that we must prepare to return to normal conditions, it is important for us to examine the question of a National Labour Code, a question, indeed, which is presently the object of much concern.

Because the war industries have ceased to produce, the Federal Government does no longer have the same reasons for intervening, and everything relating to industrial and labour relations, conciliation and arbitration, collective bargaining and the determination of wage rates must, in future, go back under the exclusive control of the provinces.

It will be evident, upon reference to the British North America Act, that most of the problems involving relations between Capital and Labour fall within the sphere of the Provinces. Section 92, subsections 13, 14 and 15 of the Act lay down the powers of the Provinces in the following terms :

( 92. In each Province the Legislature may exclusively make laws in relation to matters coming within the classes of subjects hereinafter enumerated :

13. - Property and civil rights.

14. - The administration of justice including procedure in civil matters.

15. - The imposition of punishments for enforcing any law of the province within the compass of its jurisdiction. ")

Now, the problem of relations between Capital and Labour gives rise more particularly to questions of a civil nature :

a) the contract for the hiring of help.

b) the apprenticeship contract;

c) the determination, by decree, of minimum wages;

d) the duration of work; e) the conciliation and arbitration of disputes;

$f$ ) the collective labour agreement and the procedure relating to its negotiation.

All these questions come under civil law and, consequently, fall exclusively within the scope of jurisdiction of the Provinces. The Privy Council has handed down judgment to that effect.

In asking the Federal Government to promulgate a National Code for labour relations, one does not, unfortunately, make the necessary distinctions between respective jusrisdictions of the Federal and Provincial authorities, which jurisdictions are defined in the British North America Act and interpreted by the Privy Council, after having formed the subject of a pact between the Provinces.

Promulgation a complete labour relations code is mostly legislating on civil matters.

A labour relations code embodies the principle of the right to organize, and that of free syndical action. It refers to collective labour negotiations, establishes the procedure to be followed in determining wages, working hours and holidays with pay, deals with the formulating of rules governing apprenticeship, and, finally, calls for the establishment of a procedure for the conciliation and arbitration of disputes.

We have every reason to believe that the provincial bodies actually in operation fully meet present needs and are, to a high degree, qualified to satisfy future. requirements, if, whenever necessary, we reorganize them to cope with the situation which it is within our power so to do.

The point in question here is not one of mere pclitics but a matter of social policy involving the autonomy oi the Province as well as its economic, cultural and social future. 


\title{
UN CODE PROVINCIAL DU TRAVAIL
}

\author{
N.D.L.R. A titre documentaire nous reproduisons ci-dessous un extrait d'une conférence prononcée, \\ le 16 janvier, par l'Honorable Antonio Barrette, ministre du Travail, \\ province de Québec
}

" Maintenant que nous entrons dans la période de transition et que nous devons revenir à une situation normale, il importe d'examiner la question d'un code national du travail, question qui soulève présentement - beaucoup d'intérêt.

Les industries de guerre n'existant plus, le gouvernement fédéral n'a plus les mêmes motifs d'intervention, et tout ce qui concerne les relations ouvrières et industrielles, la conciliation et d'arbitrage, la fixation des salaires et les négociations collectives, doivent être à l'avenir sous le contrôle exclusif des provinces.

Il apparaît clairement, si on réfère à l'Acte de l'Amérique britannique du Nord, que la plupart des problèmes relatifs aux relations capital-travail sont du domaine provincial. Les paragraphes 13,14 et 15 de l'article 92 de l'Acte précisent les pouvoirs des provinces dans ces termes:

“ 92. Dans chaque province, la Législature pourra exclusivement faire des lois relatives aux matières tombant dans les catégories de sujets ci-dessous énumérés :

13. - La propriété et les droits civils;

14. - L'administration de la justice y compris la procédure en matières civiles.

15. - L'infliction de punitions dans le but de faire exécuter toute loi de la province dans le cadre de sa juridiction. "

Or, le problème des relations capital-travail pose particulièrement des questions d'ordre civil :

a) le contrat de louage de service;

b) le contrat d'apprentissage;

c) la fixation, par décret, des salaires minima;

d) la durée du travail; e) la conciliation et l'arbitrage des conflits d'intérêts;

f) le contrat collectif de travail et les procédures relatives à sa négociation.

Toutes ces questions relèvent du droit civil et, conséquemment sont de la juridiction exclusive de la province. Le Conseil Privé a rendu jugement dans ce sens.

Quand on demande au gouvernement fédéral la promulgation d'un Code national de relations ouvrières, on ne fait pas malheureusement les distinctions nécessaires sur les juridictions respectives de l'autorité fédérale et de l'autorité provinciale, juridictions qui sont délimitées par l'Acte de l'Amérique britannique du Nord, interprétées par le Conseil Privé, après avoir été l'objet d'un pacte entre les provinces.

Promulguer un Code de relations ouvrières complet, c'est surtout légiférer en matières civiles.

Un Code de relations ouvrières pose le principe du droit d'association, celui de la liberté d'action syndicale, réfère aux négociations collectives de travail, détermine la procédure de fixation des salaires, de la durée du travail, des vacances payées, traite de la réglementation de l'apprentissage, oblige enfin à l'établissement d'une procédure de conciliation et d'arbitrage des conflits d'intérêts.

Nous avons toutes raisons de déclarer que les organismes provinciaux actuels répondent aux besoins de l'heure et sont éminemment qualifiés pour répondre aux besoins de l'avenir, en y faisant, s'il y a lieu, des améliorations appropriées que nous avons le pouvoir de réaliser.

Il ne s'agit pas, ici, d'une question de politique partisane mais de politique sociale qui met en jeu l'autonomie de la province, son avenir économique, cultural et social.» 


\title{
SOME CONCLUSIONS REGARDING UNION-MANAGEMENT RELATIONS
}

\author{
(as worked out by Clinton S. Golden and Harold J. Ruttenberg in their book, \\ The Dynamics of Industrial Democracy.)
}

1. Workers organize into labor unions not alone for economic motives but also for equally compelling psychological and social ones, so that they can participate in making the decisions that vitally affect them in their work and community life.

2. Collective bargaining marks the end of individual and the beginning of group relations between workers and management.

3. The initial collective-bargaining practises are influenced in paying degrees by the preunion history of the particular industrial concern and by the fact that genuine union-management relations are initiated by the union.

4. Collective bargaining is an instrument for workers and owners, through unions and management, to solve their problems directly without recourse to the government.

5. Collective bargaining is the extension of the basic principles and practises of democracy into industry.

6. The policies and actions of unions are likely to reflect the policies and actions of management.

$\gamma$. The attitudes and actions of management largely determine the degree of co-operativeness of union leadership.

8. The time lag in the growth of constructive union leadership, after management ceases its opposition, varies with the extent to which labor assumes responsibility for the development of its leaders.

9. Salesmen and purchasing agents usually possess a more natural ability for handling management's relations with unions than do operating officials.

10. The leadership requirements and responsibilities of management increase under union-management relations.

11. Participation of workers, union representatives, and management at all levels is a prerequisite to the successful administration of a collective-bargaining contract.

12. The peaceful administration of a contract requires the confidence of workers that they will get justice through the collectivebargaining machinery in the settlement of their grievances.

19. Grievances should be settled speedily and as near their point of origin as possible.

14. Grievances should be settled on their merits with no logrolling permitted.

15. Management should frankly acknowledge the role of the union in bringing about improvements in working conditions.

16. The successful administration of a contract requires the maintenance of an effective system of communications for both management and the union, in bringing complaints from the bottom up and relaying decisions and policies from the top down.

17. The nature of union-management relations and the administration of a contract are influenced greatly by the pattern of social relations in any given community.

18. Workers acquire a qualified property interest in their jobs under a collective-bargaining contract.

19. Each group of workers strives for the kind of senjority 7 rules which it thinks will provide the greatest amount of job protection,
20. Seniority is an instrument designed to eliminate favoritism and discrimination.

21. The power to discharge should not be lodged in a single person.

22. Workers should enjoy full freedom of opportunity for advancement and promotion.

23. There is no basic conflict between seniority and productive effiency.

24. A prime objective of collective bargaining is the redistribution of the proceeds of production.

25. Unions should participate with management in distribution the proceeds of each firm's production between its owners and workers.

26. The proceeds of technological changes, labor-saving machinery, and other factors contributing to lower unit costs of production should be shared equitably between owners and workers.

27. The adjustment of wage-rate inequalities should be exclusively on the basis of the merits of each case.

28. The greater the participation of workers through their unions in setting piecework and tonnage rates, in making time and motion studies, in determining work standards and job evaluations, the greater are the earnings and output.

29. Membership in the union should be a condition of employment.

30. The union shop is a necessary prerequisite for constructive union-management relations.

51. The union shop may be an instrument for either constructive or negative union-management relations, depending chiefly upon management's outlook and the caliber of unicn leadership.

32. Management's assumption of sole responsibility for productive effiency actually prevents the attainment of maximum output.

33. The participation of organized workers in management provides an outlet for their creative desires, as it is essentially a creative and co-operative undertaking.

34. Union-management co-operation to reduce costs, eliminate wastes, increase productive efficiency and improve quality represents a practical program that provides workers with effective direct participation in the creative phases of management.

35. Union-management co-operation tends to make management more efficient and unions more cost-conscious, thereby improving the competitive position of a business enterprise and increasing the earnings of both workers and owners.

36. The natural outgrowth of local-plant and individual-company collective bargaining is bargaining between district or industrywide organizations of management and unions.

37. The future of industrial democracy depends upon the attainment of full production and employment on a sustained basis during and after the war.

(Extrait de Workers and Bosses are Human, Public Affairs, Pamphlets n・ 76.) 


\section{FACTEURS NOUVEAUX DANS L'AMÉNAGEMENT DES RELATIONS DU TRAVAIL}

(Suite de la page 2)

comprendre les comportements humains, l'économique, pour déterminer la répartition des biens entre les facteurs de production, la mécanique, pour adapter le travail aux hommes qui auront a l'exécuter, le droit, pour appliquer les lois du pays au contrat de travail et, enfin, la morale, parce que tous ces rapports sont des rapports humains qui doivent être justes et tenir compte de la grande vertu de prudence.

Employeurs et employés ont des iṇtérêts communs, mais aussi des exigences divergentes qu'il faut concilier en insistant sur les avantages mutuels qu'ils retireront de relations industrielles à base de justice et de charité. L'adaptation est difficile et exige beaucoup d'éducation et de vertu. Cependant, il ne faut pas se décourager, car il y va du bien-être et de la sécurité commune. Heureusement, beaucoup d'employeurs et beaucoup d'union ouvrières ont compris leurs responsabilités et admettent de plus en plus les changements opportuns qui s'imposent dans la manière de concevoir ces relations.

Gerard Dion.

\section{CONFLITS ET ARBITRAGE}

\section{(Suite de la page \$)}

maintenant qualifiée d'immorale? Ce serait le retour aux règlements de force, à la guerre.

Dans le cadre même des conflits individuels de droit ou d'intérêts, qui songe à retourner au système de la jungle ? Qui prétend que la force doit primer le droit?

L'autorité publique a donc raison dans le champ des conflits du travail d'imposer le recours à la procédure arbitrale. On l'a utilisée durant la guerre avec succès. Que les résultats obtenus nous instruisent et nous servent ! Il ne faudrait pas que la démocratie devienne un laboratoire d'incubation de l'anarchie sous la crainte d'être taxée de procédés totalitaires et qui loin d'en être, ne sont que l'expression d'une société juridiquement organisée.

Enfin, il est essentiel que patrons et ouvriers comme du reste l'Etat lui-même reviennent aux valeurs spirituelles. Le bonheur des hommes n'est pas nécessairement en équation avec hauts salaires et gros profits. La conscience des hommes doit regarder ailleurs et plus haut. Autrement, quels que soient les codes du travail et la bonne volonté des gouvernants, les hommes finiront par perdre leur liberté, sacrifiée sur l'autel d'une société, qui, pour se défendre, devra les enchainer dans la prison du totalitarisme, sous le signe du communisme ou du fascisme ou de variantes faciles à créer.

Ggrard Tremblay.

\section{BIBLIOGRAPHIE}

Cette liste, forcément incomplete, indique, sans approuver pour autant leur contenu, certaines publications recentes ou le lecteur pourra se renseigner sur l'évolution des idtes et des faits dans le domaine des relations industrielles.

\section{PÉriodiques \\ CANADA}

Wage Rates and Purchasing Power, Charles Marlowe - The Labour Review, décembre 1945, Ottawa.

De la méfiance à la collaboration, Jean-Pierre Després - La Revue Dominicaine, janvier 1946, Montréal.

Conflits industriels réglés en vertu des règlements des relations ouvrières en temps de guerre - La Gazette du Travail, décembre 1945, Ottawa.

Activité du ministère du Travail durant la guerre - La Gazette du Travail, décembre 1945, Ottawa.

Labour-Management Conference in United States - The Labour Gazette, décembre 1945, Ottawa.

The Maintenance of Full Employment after the Transition Period : A Comparison of the Problem in the United States and the United KIngdom, M. KALECKI - International Labour Review, novembre 1945, Montréal.

How Unions Feel About Foremen, A. R. Mosher - The Canadian Unionist, janvier 1946, Ottawa.

What a Health Plan Means to Industry, Dr F. D. Cruickshank The Canadian Unionist, janvier 1945, Ottawa.

La décision du juge Rand, R. HAChetre - Le Monde Ouvrier, 2 février 1946, Montréal.

L'entreprise privée devant les tendances socialistes modernes, Joseph SchUMPETER - Relations, février 1946, Montréal.

Labor's Finger in Management's Pie, Benjamin L. Masse A merica, 2 février 1046, New-York.

L'assurance-chômage, élóment de sécurité sociale au Canada, Louis-J. TrotTIER - L'Actualité Economique, janvier 1946, Montréal.

\section{ETATS-UNIS}

French State Bureaucracy and It's Employees, Pat.l Vignaux The New Leader, 24 janvier 1946, New-York.

Was the Labor Crisis Necessary, J. A. Livingston - The Saturday Evening Post, 24 janvier 1946, Philadelphie.

Resistance to Shop Changes, Benjamin M. Selekman - Harvard Business Review, Automne 1945.

Productivity «Per Man-Hour"-Trusts and Estates, novembre 1945.

Functions and Limitations of Job Evaluation, Robert TrLove Personnel, janvier 1946.

Building Employee Security, Leland P. Bradforn-Personnel, janvier 1946.

Making Employer-Employee Cooperation Practicable, Milton HaLl et William P. M ALlard - Personnel, janvier 1946. 